\title{
Overview of management of children with COVID-19
}

\author{
Dyah Kanya Wati, MD, PhD ${ }^{1}$, Arya Krisna Manggala ${ }^{2}$ \\ ${ }^{1}$ Pediatric Emergency and Intensive Care Sanglah Public Hospital, School of Medicine, Udayana University, Denpasar, Bali, Indonesia \\ ${ }^{2}$ School of Medicine, Udayana University, Denpasar, Bali, Indonesia
}

The widespread and contagious coronavirus disease 2019 (COVID-19) caused by severe acute respiratory syndrome coronavirus 2 has become a burden in the global health domain. The subsequent discovery of the virus features and pathogenesis, and prompt and adequate management are still lacking and remain inconclusive. Children usually present milder symptoms than adults, and management focuses on providing symptomatic and respiratory supports. Several treatment modalities, including the utilization of mechanical ventilation (MV), antivirals, immune-modulating drugs, or other agents, may present promising results in reducing the symptoms of COVID-19, particularly in severe cases. Although no randomized clinical trials have been published to date, it is interesting to explore potential modalities for treating COVID-19 in children, based on review articles, case reports, and recent guidelines.

Key words: Child, COVID-19, Treatment

\section{Key message}

The specific treatments for COVID-19 in children remain inconclusive and debatable despite effectively decreasing its signs and symptoms.

The need for clinical trials and reports should be investigated.

\section{Introduction}

The number of people infected with novel coronavirus disease 2019 (COVID-19) to date remains significantly high. ${ }^{1,2)}$ As of June 30, 2020, this pandemic and Public Health Emergency of International Concern, as labeled by the World Health Organization (WHO), ${ }^{2,3)}$ has infected more than 10 million people of all ages and caused more than 500,000 deaths in almost every country worldwide. ${ }^{4)}$ This novel coronavirus is going to defeat the previous severe acute respiratory syndrome coronavirus (SARS-CoV) and Middle East respiratory syndrome coronavirus (MERS-CoV) in terms of confirmed and death cases. ${ }^{5)}$ The first report of this new emerging disease was in
Wuhan, Hubei province in China, where affected individuals visited the hospital with pneumonia of unexplained etiology at the end of December 2019. ${ }^{6}$ It was speculated that Wuhan's Huanan Seafood Wholesale Market, which sold edible wild animals, was associated with the source of the outbreak, as more than $60 \%$ staff there presented with symptoms. ${ }^{1,6-8)}$ On January 7,2020 , the first isolated virus from patients was discovered by Chinese scientists, who named it SARS-CoV-2 due to similar phylogenetic results to the previous SARS-CoV. ${ }^{(-9)}$

Children appear to be less susceptible to the COVID-19 infection and show milder symptoms than adults. ${ }^{10-13)} \mathrm{A}$ retrospective study in Zhejiang of 36 children revealed that all showed mild and moderate symptoms and none showed severe or critical symptoms. Furthermore, the most frequent symptoms were fever (36\%), followed by cough (19\%), sore throat (3\%), and dyspnea (3\%); 28\% were asymptomatic. ${ }^{14)}$ The reason beyond this phenomenon remains questionable, yet some hypotheses have been explained and progressively investigated. ${ }^{15-17)}$

A recent study revealed that the levels of angiotensin-converting enzyme 2 (ACE-2), a proven binding site of SARS-CoV -2 , are lower in the upper (nasal) and lower (bronchial epithelial tissue) airways within the pediatric versus adult population. ${ }^{18)}$ Milder symptoms of COVID-19 in children also might be associated with "trained immunity," which is formed by the innate immunity system that exhibits immune memory or nonspecific effects after antigen exposure. ${ }^{16,19,20)}$ The maternal antibodies are transferred from mother to child and have an interesting role in protecting children from infection during the first month of life, when the immune system is still immature. ${ }^{21,22)}$ The children also showed absence of comorbidities related to the aging process that is commonly found in older individuals. ${ }^{15}$ )

Those protective mechanisms in children could help improve therapeutic strategies. Nevertheless, the exact pathogenesis of this disease is mystifying since its main treatments involve sym. ptomatic and respiratory supports alone due to the limited role of antivirals, immune modulators, or other possible modalities. 23) Furthermore, although remained uncertain due to lack of clinical trials, several studies reported on the treatment of COVID-19 infection in children. Therefore, here we aimed to

\footnotetext{
Corresponding author: Dyah Kanya Wati, MD, PhD. Department of Child Health, School of Medicine, Udayana University, Sanglah Public Hospital, Jalan Diponegoro, Dauh Puri Klod, West Denpasar, Denpasar City, Bali Province, 80113, Indonesia

凶E-mail: dyahpediatric@yahoo.com, https://orcid.org/0000-0002-6633-7445

Received: 17 May, 2020, Revised: 2 July, 2020, Accepted: 10 July, 2020

This is an open-access article distributed under the terms of the Creative Commons Attribution Non-Commercial License (http://creativecommons.org/licenses/by$\mathrm{nc} / 4.0 /$ ) which permits unrestricted non-commercial use, distribution, and reproduction in any medium, provided the original work is properly cited.

Copyright (c) 2020 by The Korean Pediatric Society
} 
provide the evidence of several modalities that have a potential role in treating COVID-19 in children based on case reports, prospective and retrospective studies, and several published guidelines.

\section{Methods}

We searched PubMed, MEDLINE, Cochrane Database, Science Direct, and Google Scholar for relevant articles. The selected full-text articles were published in English between January 1, 2020 and June 13, 2020; 2 current national guidelines were published in Indonesian. The keywords included coronavirus, SARS-CoV-2, 2019-nCOV, COVID-19, and novel coronavirus combined with children, pediatrics, treatment, therapeutic, pharmacology, and management. Most of the articles chosen were case reports and case series, retrospective and prospective studies, review articles, and recent initial guidelines. We found no randomized clinical trial of pediatric populations in the literature review. Additionally, the reference lists of the selected articles were manually reviewed to identify any other articles that were relevant to the topic. The studies were mostly from China with similar numbers from Iran and Spain.

\section{Epidemiology of covid-19 in children}

The first pediatric case of COVID-19 was described through a familial cluster of pneumonia in Shenzen, China, on January 20, 2020. A 10-year-old boy who traveled from Wuhan with his relatives reportedly presented asymptomatic behavior, but a ground glass appearance was seen on a computed tomography scan and a positive result was obtained by polymerase chain reaction. ${ }^{24)}$ Epidemiologically, in a retrospective study of 366 children younger than 16 years with respiratory symptoms, only $6(1.6 \%)$ tested positive for SARS-CoV-2. ${ }^{25)}$ A series of nearly 1,400 children from Wuhan Children's Hospital treated between January 28, 2020 and February 26, 2020 revealed SARS-CoV-2 positivity in $171(12.3 \%){ }^{26)}$ Another larger study regarding the epidemiological characteristics of 2,143 children in China reported 731 laboratory-confirmed cases (34.1\%) of SARS-CoV-2. ${ }^{27)}$ Similar findings were reported in several countries. In the United States (US), among approximately 150,000 cases, 2,572 (1.7\%) were children younger than 18 years; of them, 3 died. ${ }^{28)}$ In Italy, COVID-19 infected 1\% children aged 0-18 years, with $11 \%$ being hospitalized and no fatalities being reported. ${ }^{29)}$ A current report from Korea stated that COVID-19 infected 480 children (6.2\%) under 19 years of age with no cases of mortality. ${ }^{13)}$ Here in Indonesia, the latest data show that $8 \%$ of children younger than 17 years of age have confirmed COVID-19 with a $1.7 \%$ fatality rate. ${ }^{30}$

\section{Treatment modalities}

\section{General and supportive treatment}

1) Supportive therapy

Bed rest and supportive treatment such as ensuring an adequate intake of daily calories and water; monitoring water and electrolyte balance, vital signs, and oxygen saturation; and performing routine blood or urine examinations or assessing other biochemical parameters based on clinical conditions, blood gas analyses, and serial chest imaging examinations should be provided when facilities are adequate. Patients can be administered physical cooling or antipyretic drugs (oral ibuprofen or acetaminophen) for a body temperature above $38.5^{\circ} \mathrm{C} .{ }^{10,31)}$ In addition, a recent multicenter panel of pediatric infectious diseases physicians and pharmacists from North American institutions released the initial guideline statement on April 22, 2020 stating that outpatients and hospitalized patients with mild or moderate COVID-19 (no new supplemental oxygen requirement) should be managed with supportive care only. ${ }^{23}$

In addition to receiving supportive therapy, most patients within the two studies also received received oxygen therapy due to hypoxemia upon admission. ${ }^{17,32)}$ Only one 3-year-old female child with severe manifestation of respiratory disease shown by ground glass opacity in both lungs received supplemental oxygen. She also received intravenous immunoglobulin (IVIG) from healthy donors. ${ }^{25)}$ Cai et al. ${ }^{33)}$ reported that, for 10 patients, supportive therapy was given with no need for oxygen therapy (Table 1).

2) MV in the pediatric intensive care unit

The role of supportive treatment for maintaining breathing and airway is provided by noninvasive MV, such as high-flow nasal cannula, continuous positive airway pressure, or bi-level positive airway pressure, which are used for severe and critical cases in pediatric patients who develop the symptoms of acute respiratory distress syndrome (ARDS). ${ }^{10,23,34)}$ A case series in Iran reported that 2 of 9 patients received noninvasive continuous positive airway pressure in the pediatric intensive care unit (PICU). These 2- and 10-year-old patients had mild hypoxemia and respiratory distress with saturations of 78\%-90\% and 68\%, respectively. ${ }^{32)}$ Sun et al. ${ }^{17)}$ reported on 2 critically ill children who underwent invasive MV. Moreover, in a case series in Spain, García-Salido et al. ${ }^{35)}$ described that nearly all children with COVID-19 presented increased respiratory effort and required oxygen therapy through a nasal cannula. Furthermore, of the 5 who received high-flow nasal cannula support, 4 subsequently required noninvasive ventilation (NIV) and the other required MV upon PICU admission.

\section{3) Antibiotics}

Antibiotics should be used only in patients with secondary bacterial infections based on culture and antibiogram results. ${ }^{36}$ The irrational administration of antibiotics should not to be practiced, particularly combined with broad-spectrum antibiotics. 
Table 1. Studies describing the treatment of COVID-19 in children

\begin{tabular}{|c|c|c|c|c|c|c|}
\hline & Sun et al. ${ }^{17)}$ & Lou et al. ${ }^{40)}$ & Cai et al. ${ }^{33)}$ & Rahimzadeh et al. ${ }^{32)}$ & Liu et al. ${ }^{25)}$ & García-Salido et al. ${ }^{35)}$ \\
\hline Publication date & 19 March 2020 & 22 March 2020 & 28 February 2020 & 1 April 2020 & 2 April 2020 & 22 May 2020 \\
\hline Design of study & Retrospective study & Case report & Case series & Case series & Retrospective study & $\begin{array}{l}\text { Prospective obser- } \\
\text { vational study }\end{array}$ \\
\hline Country & China & China & China & Iran & China & Spain \\
\hline \multicolumn{7}{|l|}{$\begin{array}{l}\text { Characteristics of } \\
\text { patients }\end{array}$} \\
\hline Number & 8 & 3 & 10 & 9 & 6 & 7 \\
\hline Age & 2 months -15 years & 6 months- 8 years & 3 months- 11 years & 2 years -10 years & 1 year-7 years & 0.5 month-13 years \\
\hline Sex, male:female & $6: 2$ & $1: 2$ & $4: 6$ & $6: 3$ & $2: 4$ & $4: 3$ \\
\hline \multicolumn{7}{|l|}{ Therapy options } \\
\hline $\begin{array}{l}\text { Antiviral } \\
\text { (including } \\
\text { antimalarial) }\end{array}$ & $\begin{array}{l}\text { All (therapy including } \\
\text { virazole, oseltami- } \\
\text { vir, and interferon) }\end{array}$ & $\begin{array}{l}\text { Nebulized interfe- } \\
\text { ron-a2b 100,000 } \\
\text { IU/kg (2 sister) }\end{array}$ & N/A & $\begin{array}{c}\text { All (7 oseltamivir; } 2 \\
\text { oseltamivir, lopina- } \\
\text { vir, and ritonavir) }\end{array}$ & $\begin{array}{l}\text { 2/6 (ribavirin) } \\
\text { All oseltamivir }\end{array}$ & $\begin{array}{l}\text { All patients (6 lopina- } \\
\text { vir and ritonavir, } 1 \\
\text { remdesivir) } \\
6 / 7 \text { (hydroxychloro- } \\
\text { quine) }\end{array}$ \\
\hline Antibiotics & $5 / 8$ & N/A & $\begin{array}{l}\text { 5/10 (due to pneu- } \\
\text { monia) }\end{array}$ & $\begin{array}{l}\text { All (meropenem, van- } \\
\text { comycin, chloroqu- } \\
\text { ine) }\end{array}$ & All & $\begin{array}{l}\text { 6/7 (broad-spectrum } \\
\text { antibiotics due to } \\
\text { suspected bacterial } \\
\text { infection) }\end{array}$ \\
\hline Corticosteroid & $5 / 8$ & N/A & N/A & N/A & $4 / 6$ & $5 / 7$ \\
\hline $\begin{array}{l}\text { Mechanical } \\
\text { ventilation }\end{array}$ & 2/8 (critically ill) & N/A & N/A & $\begin{array}{l}\text { 2/9 (using noninva- } \\
\text { sive continuous po- } \\
\text { sitive airway pres- } \\
\text { sure) }\end{array}$ & N/A & $4 / 7$ \\
\hline Oxygen therapy & $6 / 8$ & $\mathrm{~N} / \mathrm{A}$ & $\mathrm{N} / \mathrm{A}$ & All & $\begin{array}{l}\text { 1/6, supplemental } \\
\text { oxygen }\end{array}$ & All \\
\hline Others & $\begin{array}{l}\text { Traditional Chinese } \\
\text { medicine (4/8) } \\
\text { Plasmapheresis (1/8) } \\
\text { Immunoglobulin (4/ } \\
\text { 8) }\end{array}$ & N/A & $\begin{array}{l}\text { Supportive treat- } \\
\text { ment with no need } \\
\text { oxygen therapy to } \\
\text { all patients }\end{array}$ & N/A & $\begin{array}{l}\text { Immunoglobulin (1/ } \\
6)\end{array}$ & $\begin{array}{l}\text { Immunoglobulin }(2 / \\
7) \\
\text { tocilizumab }(2 / 7) \\
\text { Heparin }(3 / 7 \text {, thera- } \\
\text { peutic and prophy- } \\
\text { lactic of thrombo- } \\
\text { sis) }\end{array}$ \\
\hline Prognosis & $\begin{array}{l}5 \text { Discharged } \\
3 \text { Remained in PICU } \\
\text { (up to February 24, } \\
\text { 2020) }\end{array}$ & $\begin{array}{l}\text { Discharged after } \\
10 \text { days admis- } \\
\text { sion }\end{array}$ & All discharged & $\begin{array}{l}\text { Discharged within } 6 \\
\text { days }\end{array}$ & $\begin{array}{l}\text { Duration of hospita- } \\
\text { lization: 5-13 days }\end{array}$ & $\begin{array}{l}6 \text { Discharged (dura- } \\
\text { tion: } 2-31 \text { days) } \\
1 \text { Remained in PICU }\end{array}$ \\
\hline
\end{tabular}

COVID-19, coronavirus diseases 2019; N/A, not available or not mentioned in the study; PICU, pediatric intensive care unit.

Antibiotics might be used in situations of bacterial coinfection; therefore, specimen collection to confirm the pathogenic etiology should be performed. ${ }^{31)}$ The administration of antibiotics was previewed by García-Salido et al., ${ }^{35)}$ who mentioned that almost all patients were treated empirically with broad-spectrum antibiotics based on clinical suspicion; however, positive bacterial culture was observed in only 2 children.

\section{Antivirals and antiviral-like drugs, including anti-influenza drugs}

1) Antivirals

The national recommendations for the diagnosis and treatment of pneumonia caused by the novel coronavirus (2019$\mathrm{nCoV})$ released by Zhejiang University School of Medicine on February 2, 2020 stated that there are no effective antiviral drugs for children. ${ }^{37}$ In addition, the multicenter intial guideline statement on April 22, 2020 stated that antivirals may be considered in children with confirmed COVID-19 virology on a case-by-case basis. Moreover, enrollment in clinical trials to learn the efficacy and safety of their potential is recommended. Antivirals also should be offered with proper monitoring and in consultation with a pediatric specialist whenever possible. ${ }^{23)}$ The current interim guideline published by the $\mathrm{WHO}$ recommends that antivirals not be given for treatment or prophylaxis in COVID-19 unless clinical trials are performed. ${ }^{34)}$

\section{(1) Interferon}

Interferon-alpha (IFN- $\alpha$ ) is a broad-spectrum antiviral drug that inhibits viral RNA synthesis and replication. A previous study showed that IFN- $\alpha$ combined with ribavirin could inhibit viral replication, thus improving clinical outcomes in a MERS$\mathrm{CoV}$ animal study ${ }^{38,39)}$ It also decreases the viral load at the start of the infection, which can help relieve symptoms. IFN- $\alpha$ in China is also usually applied to manage viral pneumonia, bronchiolitis, SARS, acute upper respiratory tract infections, hand foot and mouth disease, and other viral infections in children. ${ }^{31)}$

The option of antiviral treatment of IFN- $\alpha$ nebulization is divided according to symptom severity: Children with mild 
disease are administered 100,000-200,000 IU/kg, while those with severe disease could be given 200,000-400,000 IU/kg in 2 $\mathrm{mL}$ of sterile water twice daily for $5-7$ days, ${ }^{31,37)}$ while high-risk populations in close contact with suspected COVID-19-infected patients or patients in the early phase with only upper respiratory tract symptoms could be administered IFN- $\alpha 2 b$ spray. The IFN$\alpha 2 \mathrm{~b}$ should be administered as $1-2$ sprays to each nasal cavity or $8-10$ sprays to the oropharynx. The dose of IFN- $\alpha 2 b$ per injection is $8000 \mathrm{IU}$ once every 1-2 hours for a total of $8-10$ sprays/day for $5-7$ days. ${ }^{31,37,38)}$

Sun et al. ${ }^{17)}$ treated 8 severely or critically ill patients infected with COVID-19, at Wuhan Children's Hospital ICU and provided all patients with IFN in conjunction with ribavirin and oseltamivir. Five patients were discharged and 3 remained in the ICU until February 24, 2020. Lou et al. ${ }^{40)}$ described treating 2 sisters infected with COVID-19 with nebulized IFN- $\alpha 2 b$ 100,000 $\mathrm{IU} / \mathrm{kg}$ twice daily for 7 days. However, it was not administered to a third patient, an infant. The fever resolved within 3 days and the other symptoms improved signicantly after 1 week. All were discharged after 10 days.

The administration of IFN- $\alpha$ is contraindicated in patients with abnormal liver function. Its use is also prohibited in children with a creatinine clearance below $50 \mathrm{~mL} / \mathrm{min}$ or who have a history of mental illness, aplastic anemia, or severe or unstable heart disease. IFN- $\alpha$ nebulization in neonates and infants younger than 2 months should be monitored intensively. ${ }^{38)}$

\section{(2) Lopinavir/ritonavir}

Lopinavir/ritonavir (LPV/r), which is clinically approved by the US Food and Drug Administration (FDA) to combat human immunodeficiency virus (HIV) with other oral combination drugs, showed promising results against novel coronavirus through the repression of 3-chymotrypsin-like protease in vitro. It has been used clinically to treat SARS and MERS. ${ }^{38,41)}$ Another current in vitro study highlighted that $\mathrm{LPV} / \mathrm{r}$ could reduce the cytopathic effects and viral load of inoculated SARS-CoV-2 culture. ${ }^{42)}$ The ritonavir component inhibits the CYP3A metabolism of lopinavir, thus enhancing lopinavir plasma levels. It is a recommended therapy for children aged 2 weeks to 3 years who require antiretroviral therapy and for those older than 3 years who require alternative therapy. ${ }^{23)}$ The panel was divided about whether LPV/r could or should be considered for use in any children with COVID-19 in any clinical scenario. Furthermore, the panel proposed avoiding the use of combination therapy of $\mathrm{LPV} / \mathrm{r}$ and ribavirin. ${ }^{23)}$

Oral LPV/r solution is more comfortable for children who are unable to swallow tablets or have a body surface area less than $0.6 \mathrm{~m}^{2}{ }^{38)}$ The dosage regimen of $\mathrm{LPV} / \mathrm{r}$ in the form of tablets (lopinavir/ritonavir [200 mg/50 mg]) was based on body weight (BW). Children weighing 7-15 kg should be given $12 \mathrm{mg} / 3 \mathrm{mg} /$ $\mathrm{kg}$ each time; $15-40 \mathrm{~kg}, 10 \mathrm{mg} / 2.5 \mathrm{mg} / \mathrm{kg}$ each time; and $40 \mathrm{~kg}$ or more, $400 \mathrm{mg} / 100 \mathrm{mg}$ (same as adults) each time. The tablets and oral solution are administered twice daily for $1-2$ weeks. ${ }^{37,38)}$

A case series in Iran reported that 2 of 9 children with
COVID-19 were administered oseltamivir and LPV/r, while 7 others were administered oseltamivir only. $\mathrm{LPV} / \mathrm{r}$ was added to the treatment protocol for 2 patients who did not tolerate the symptoms for more than 2 days. All the patients were discharged within 6 days. ${ }^{32)} \mathrm{A}$ similar study by García-Salido et al. ${ }^{35)}$ authorized the use of $\mathrm{LPV} / \mathrm{r}$ in nearly all pediatric patients.

Lopinavir should be avoided for patients with hepatic insufficiency since it is metabolized in the liver. Other adverse effects include diarrhea, vomiting, and rash. Its use should be restricted to patients with QT interval extension syndrome and hypokalemia. $^{38)}$

(3) Ribavirin

Another broad-spectrum antiviral agent, ribavirin, which has the ability to block RNA and DNA viral synthesis, is suggested to be harmful in SARS-CoV-2 and MERS-CoV. ${ }^{41,43)}$ The administration of ribavirin to children younger than 6 years is not recommended in China. However, it is available for children older than 6 years. Ribavirin is also accessible in oral form in the USA and Europe, where its administration is recommended for children aged 3 years or older. Ribavirin injections in the form of IV infusions at $10 \mathrm{mg} / \mathrm{kg}$ each time 2-3 times per day are suggested in children with COVID-19 at a maximum dose of 500 mg each time. ${ }^{38)}$

Another correspondence study involving 6 children in Wuhan published in early January 2020 reported that ribavirin was administered to 2 of 5 patients; among them, one had severe respiratory illness and was transferred to the PICU. There is insufficient information regarding the dosages administered to patients. ${ }^{25)}$

Ribavirin should be restricted in patients with liver function problems, and its use is not recommended if laboratory tests show a creatinine clearance below $50 \mathrm{~mL} / \mathrm{min}$. Ribavirin also should be stopped if the serum creatinine level exceeds $2 \mathrm{mg} / \mathrm{dL}$. The most common side effects of ribavirin are fever, headache, hemolytic anemia, neutropenia, and fatigue. ${ }^{38)}$ The panel remarked that the combination of $\mathrm{LPV} / \mathrm{r}$ with ribavirin is not recommended due to ribavirin toxicity and a lack of evidence regarding its efficacy and safety. ${ }^{23)}$

\section{(4) Remdesivir}

Remdesivir, a prodrug of monophosphate, is active against Coronaviridae and Flaviviridae upon being metabolized to an active analog of $\mathrm{C}$-adenosine nucleoside and can bind to viral RNA-dependent RNA polymerase, leading to early RNA chain deletion. ${ }^{23,41)}$ It is a promising therapeutic class for COVID-19 because of its broad-spectrum activity and has been shown effective against SARS-CoV-2 in both in vitro and animal stud. ies. Furthermore, the study remarked that remdesivir could inhibit viral infection in a human cell line that is sensitive to COVID-19.4) The FDA recently released an Emergency Use Authorization to approve the immediate use of remdesivir for the treatment of suspected or laboratory-confirmed COVID-19 in adults and children with severe disease. ${ }^{45)}$ The panel guidance 
also recommended treatment with remdesivir in children as the preferred agent if an antiviral should be administered. ${ }^{23)}$

A recent cohort study led by Grein et al. ${ }^{46)}$ explored the preliminary findings of clinical outcomes of remdesivir administration in 53 adult patients with severe COVID-19. After receiving the first dose of remdesivir, $68 \%$ patients showed clinical improvement and $15 \%$ showed worsening outcomes. In contrast, 7 of patients (13\%) died after remdesivir treatment, including 6 who required invasive ventilation and 1 who required noninvasive oxygen support. García-Salido et al. ${ }^{35)}$ published the only study of remdesivir administration in children in which, among 7 children with COVID-19 who presented critically ill symptoms, only 1 was administered remdesivir along with immunoglobulin and tocilizumab. The patient previously received a hematopoietic stem cell transplantation. At the time the study was published, the patient was still hospitalized.

The recommended dose of remdesivir is as follows. For children with a BW of $3.5-40 \mathrm{~kg}$, use remdesivir for injection $100 \mathrm{mg}$, lyophilized powder only. Remdesivir injection $100 \mathrm{mg} /$ $20 \mathrm{~mL}(5 \mathrm{mg} / \mathrm{mL})$ should not be used for children with a BW of $3.5-40 \mathrm{~kg}$ due to the higher tonicity of the solution concentrate compared to the lyophilized formulatione. The loading dose of remdesivir is $5 \mathrm{mg} / \mathrm{kg}$ IV (infused over 30-120 minutes) on the first day, followed by $2.5 \mathrm{mg} / \mathrm{kg}$ IV (infused over 30-120 minutes) once daily for 9 days, or for 4 days for children who do not need invasive MV and/or extracorporeal membrane oxygenation (ECMO) (days 2-5). If the administration does not result in clinical improvement, it may be lengthened for up to 5 extra days (total of 10 days). For children with a BW $\geq 40 \mathrm{~kg}$ who require invasive $\mathrm{MV}$ and/or ECMO, the adult dosage regimen of one loading dose of remdesivir $200 \mathrm{mg}$ IV (infused over 30-120 minutes) on the first day, followed by $100 \mathrm{mg}$ IV (infused over
30-120 minutes) once daily for 9 days could be administered. In addition, in children with a $B W \geq 40 \mathrm{~kg}$ who do not require invasive $\mathrm{MV}$ and/or ECMO, the adult dosage regimen of one loading dose of remdesivir $200 \mathrm{mg}$ IV (infused over 30-120 minutes) on the first day followed by remdesivir $100 \mathrm{mg}$ IV (infused over 30-120 minutes) once daily for 4 days (days 2-5) could be given (Table 2). ${ }^{45)}$

Remdesivir use should be avoided in infants and children (>28 days) with an estimated glomerular filtration rate of less than $30 \mathrm{~mL} / \mathrm{min}$ and in full-term neonates (7-28 days) with a serum creatinine level of more than $1 \mathrm{mg} / \mathrm{dL}$ unless the benefit outweighs the risk. Since the common adverse effect of remdesivir is elevated liver transaminase level, ${ }^{46}$ ) the hepatic laboratory parameters should be routinely monitored in all patients before its administration. ${ }^{45)}$

2) Antimalarials including chloroquine and hydroxychloroquine

Chloroquine and hydroxychloroquine are widely used to prevent and treat malaria, amoebiasis, and autoimmune diseases. They prevent fusion into host cells by several mechanisms, including inhibiting the glycosylation of ACE- 2 receptors, acting as proteolytics, and increasing the acidification of the endosomal cells. ${ }^{41)}$ Their role as broad-spectrum antiviral drugs has been emphasized. Several clinical trials in adults and in vivo studies reported promising results in terms of reducing viral load, although this remains debatable due to methodologic limitations. Studies are limited, particularly those with larger sample sizes and in pediatric populations..$^{38,41)}$ Therefore, guidance is lacking on the dosage administration of chloroquine for treating COVID-19 in children. ${ }^{38)}$

The recent initial guideline stated that hydroxychloroquine

Table 2. Recommended dose of remdesivir based on the U.S. Food and Drug Administration formulation ${ }^{45}$

\begin{tabular}{|c|c|c|c|c|c|c|c|}
\hline \multirow{2}{*}{$\begin{array}{l}\text { Weight } \\
\text { (kg) }\end{array}$} & \multirow{2}{*}{$\begin{array}{l}\text { Require invasive } \\
\text { mechanical ventilation } \\
\text { and/or ECMO }\end{array}$} & \multirow[b]{2}{*}{ Dosage } & \multirow[b]{2}{*}{ Formulation } & \multicolumn{4}{|c|}{ Duration } \\
\hline & & & & Day & $\begin{array}{l}\text { Infusion bag } \\
\text { volume }^{\text {b) }}\end{array}$ & $\begin{array}{l}\text { Infusion time } \\
\text { (min) }\end{array}$ & $\begin{array}{l}\text { Rate infusion } \\
(\mathrm{mL} / \mathrm{min})\end{array}$ \\
\hline \multirow[t]{4}{*}{$3.5-40$} & \multirow[t]{4}{*}{ No } & \multirow[t]{2}{*}{5 mg/kg IV (single dose) } & \multirow{9}{*}{$\begin{array}{l}\text { Remdesivir for injection, } 100 \\
\text { mg, lyophilized powder only } \\
\text { (Reconstitute with } 19 \mathrm{~mL} \text { of } \\
\text { Sterile Water for Injection and } \\
\text { dilute in 0.9\% saline prior to } \\
\text { administration) }\end{array}$} & Day 1 & $100 \mathrm{~mL}$ & 30 & 3.33 \\
\hline & & & & & & 60 & 1.67 \\
\hline & & \multirow[t]{2}{*}{$2.5 \mathrm{mg} / \mathrm{kg}$ IV (single dose) } & & \multirow{2}{*}{ Days 2-5 } & & 120 & 0.83 \\
\hline & & & & & $50 \mathrm{~mL}$ & 30 & 1.67 \\
\hline \multirow[t]{5}{*}{$3.5-40$} & \multirow[t]{5}{*}{ Yes } & \multirow[t]{2}{*}{5 mg/kg IV (single dose) } & & \multirow[t]{2}{*}{ Day 1} & & 60 & 0.83 \\
\hline & & & & & & 120 & 0.42 \\
\hline & & \multirow[t]{3}{*}{2.5 mg/kg IV (single dose) } & & \multirow[t]{3}{*}{ Days 2-10 } & \multirow[t]{3}{*}{$25 \mathrm{~mL}$} & 30 & 0.83 \\
\hline & & & & & & 60 & 0.42 \\
\hline & & & & & & 120 & 0.21 \\
\hline \multirow[t]{3}{*}{$\geq 40$} & \multirow[t]{3}{*}{ No } & \multirow[t]{2}{*}{200 mg IV (single dose) } & \multirow{6}{*}{$\begin{array}{l}\text { Remdesivir injection (Dilute re- } \\
\text { mdesivir injection concentrat- } \\
\text { ed solution in } 0.9 \% \text { saline } \\
\text { prior to administration) or re- } \\
\text { mdesivir for injection }\end{array}$} & \multirow[t]{2}{*}{ Day 1} & \multirow[t]{3}{*}{$250 \mathrm{~mL}$} & 30 & 8.33 \\
\hline & & & & & & 60 & 4.17 \\
\hline & & 100 mg IV (single dose) & & Days 2-5a) & & 120 & 2.08 \\
\hline \multirow[t]{3}{*}{$\geq 40$} & \multirow[t]{3}{*}{ Yes } & 200 mg IV (single dose) & & \multirow[t]{2}{*}{ Day 1} & \multirow[t]{2}{*}{$100 \mathrm{~mL}$} & 30 & 3.33 \\
\hline & & & & & & 60 & 1.67 \\
\hline & & 100 mg IV (single dose) & & Days $2-10$ & & 120 & 0.83 \\
\hline
\end{tabular}

ECMO, extracorporeal membrane oxygenation; IV, intravenous.

a) May be extended up to 5 extra days if no clinical improvement is seen. ${ }^{\text {b) }}$ The total volume in several options of infusion bag packages. 
may be considered, especially in children who cannot be administered remdesivir, or it is otherwise unavailable. The panel also recommended that hydroxychloroquine not be used with azithromycin due to an increased risk of toxicity and QTc interval prolongation. ${ }^{23)}$

A case series in Iran reported that 7 of 9 children with COVID-19 were administered antibiotics such as meropenem, vancomycin, and chloroquine, while 2 others were administered meropenem and chloroquine only (Table 1 ). ${ }^{32)}$ Thus, chloroquine was given to all patients, while other antibiotics might be used to treat a particular disease such as pneumonia.

The fatal dosage of chloroquine is $50 \mathrm{mg} / \mathrm{kg}$. Intense caution should be taken when prescribing chloroquine to children. Adverse reactions include dizziness, loss of appetite, ocular toxicity, arrhythmia, drug-induced psychosis, and leukopenia. ${ }^{38)}$ Hydroxy. chloroquine has fewer adverse effects than chloroquine. There is also a lack of data to support a specific dosing regimen or therapeutic duration for the treatment of SARS-CoV-2, but an optimal duration of 5 days is commonly used. ${ }^{23)}$

\section{3) Anti-influenza agents \\ (1) Umifenovir}

Umifenovir is a broad-spectrum antiviral drug with the ability to inhibit DNA and RNA viruses that are commonly used for the prophylaxis and management of influenza. ${ }^{31,38)}$ It was also shown to be effective against SARS-CoV-2 in vitro by targeting the protein $S$ or the interaction with ACE-2 and by blocking membrane fusion of the viral envelope to the host cell. ${ }^{41,47)}$ However, umifenovir was mainly used for adults infected with COVID-19, and its efficacy and safety remain uncertain. ${ }^{31,38)}$

To date, there is no recommendation regarding the dosage regimen for umifenovir in COVID-19 pediatric patients. ${ }^{38)}$ The case reports described below (Table 1) also did not mention about the administration of umifenovir in children patients. Umifenovir should be administered cautiously in patients with liver abnormalities. Side effects include nausea, diarrhea, dizziness, and elevated serum aminotransferase. ${ }^{38)}$

\section{(2) Oseltamivir}

Oseltamivir, a neuraminidase inhibitor, is commonly used as an anti-influenza drug. Until now, it has no in vitro study against SARS-CoV-2. Its wide use in treating COVID-19 might have been overlapping due to the outbreak emerging during peak influenza season. Therefore, many patients found to be received oseltamivir until SARS-CoV-2 was invented. ${ }^{41)}$ Oseltamivir and other anti-influenza drugs could be administered to patients who are coinfected with the influenza virus and play limited role in the treatment of COVID-19 when influenza has been excluded. ${ }^{38,41,48)}$

Several case-control studies ${ }^{17,25,32)}$ administered oseltamivir to almost all of their patients with or without other combination antiviral therapy. The dosage of oseltamivir used was based on age and BW. Children younger than 1 year of age should receive $3 \mathrm{mg} / \mathrm{kg}$ every 12 hours, while those older than 1 year of age should be dosed by BW: $<15 \mathrm{~kg}, 30 \mathrm{mg}$ every 12 hours; $15-23$ $\mathrm{kg}, 45 \mathrm{mg}$ every 12 hours; $23-40 \mathrm{~kg}, 60 \mathrm{mg}$ every 12 hours; and $>40 \mathrm{~kg}, 75 \mathrm{mg}$ every 12 hours. ${ }^{48,49)}$

\section{Immune-modulating drugs}

Although children usually present with mild or moderate symptoms, cytokine storm may occur. ${ }^{50)}$ Cytokine storm is defined as the immune system yielding a dysfunctional inflammatory response that is proven to trigger worse outcomes. ${ }^{51,52)}$ It also represents the exaggerated innate response that causes lung injury. ${ }^{15,53)}$ The result of cytokine storm can be observed in patients with a severe clinical course who show ARDS as well as multiple organ failure. Cytokine storm and ARDS result from the effects of an arrangement of various immune-active molecular components, such as interleukins, interferons, chemokines, colony-stimulating factors, and tumor necrosis factors. ${ }^{51,52,54)}$ The classes of modalities used to prevent further immunologic reactions are described below.

\section{1) Corticosteroids}

Early corticosteroid treatment plays an important role in immune-mediated lung injury within the critical phase. Immunomodulators might be given in the early stage of respiratory distress showing significant symptoms, such as sudden-onset dyspnea or wheezing and the need for oxygen therapy. ${ }^{55)}$ Corticosteroids cannot only repress inflammation of the lungs, they can decrease the immune responses and increase pathogen clearance, and their use should be avoided except for those with a specific indication (e.g., bronchospasm, some cases of septic shock). ${ }^{36}$ Therefore, it should not be applied in some types of infection. ${ }^{36}$

Interim guidance of the WHO does not recommend the routine administration of corticosteroids for the treatment of viral pneumonia due to a lack of evidence. ${ }^{34)}$ The recommendation is also based on several studies that stated corticosteroid therapy did not significantly decrease the mortality rate, hospitalization duration, or need for MV but that it potentially has several adverse effects. ${ }^{56)}$ On the contrary, corticosteroids may be considered in some conditions, such as the exacerbation of asthma, septic shock, ARDS, and after the adjustment for risks or benefits on a case-by-case basis. ${ }^{34)}$ It also can be considered in cases of toxic symptoms, encephalitis or encephalopathy, or hemophagocytic syndrome. ${ }^{31,37)}$

In a case-control study of Ahn et al..$^{57)}$ of 2 older patients who developed ARDS with COVID-19, the administration of $0.5-1$ $\mathrm{mg} / \mathrm{kg} /$ day methylprednisolone showed rapid resolution in serial laboratory and oxygenation parameters as well as chest radiology findings. Glucocorticoids were administered to pediatric patients in 2 case reports published by Sun et al. ${ }^{17)}$ and Liu et al. ${ }^{25)}$ Glucocorticoids can be used for 3-5 days, mainly as methylprednisolone $1-2 \mathrm{mg} / \mathrm{kg} /$ day IV; their long-term use is not recommended. ${ }^{31,37)}$ 
2) Intravenous immunoglobulin

IVIG is a promising modality for treating COVID-19 from the immunological perspective. This preparation shows viral cross-reactivity, including SARS-CoV-2 in vitro, by neutralizing inflammatory cytokines, which are believed play a pivotal role in the development of the disease's severity. ${ }^{58)}$ The applicability of this modality has been explored in some cases overlapping with COVID-19 in children.

Recent reports in Europe and the US revealed a growing phenomenon of a small cases of multisystem inflammatory condition in children and adolescents (MIS-C), describing cases of children with COVID-19 who have manifestations similar to those of Kawasaki disease and toxic shock syndrome. This kind of hyperinflammatory response may lead to multiorgan failure and shock. ${ }^{59)}$

Riphagen et al. ${ }^{60)}$ reported on 8 children with the MIS-C, 2 of whom tested positive for SARS-CoV-2. All children were given IVIG $2 \mathrm{~g} / \mathrm{kg}$ in the first 24 hours. One who tested positive for SARS-CoV-2 died, while the other was discharged after 4 days in the PICU. The case study of a 6-month-old girl with symptoms consistent with those of Kawasaki disease tested positive on reverse transcription polymerase chain reaction for SARS-CoV-2 after testing negative on an early examination. She had been administered a single dose of IVIG $2 \mathrm{~g} / \mathrm{kg}$ and showed clinical improvement afterward. ${ }^{61)}$ The administration of IVIG to patients with COVID-19 without any symptoms of Kawasaki disease or toxic shock syndrome was described by Sun et al. ${ }^{17)}$ and Liu et al., ${ }^{25)}$ who had administered IVIG to 4 of 8 and 1 of 6 patients, respectively.

Based on the guideline, it is suggested that IVIG $1 \mathrm{~g} / \mathrm{kg} /$ day for 2 days or $400 \mathrm{mg} / \mathrm{kg} /$ day for 5 days be given for patients with severe disease despite its efficacy still requiring investigation in a larger study. ${ }^{31,37)}$

\section{3) Monoclonal antibody}

As mentioned above, the cytokine storm is activated by an augmented immune response and cytokine release. ${ }^{41)}$ Studies mentioned that interleukin-6 (IL-6) is a crux of this diminishing inflammation process. ${ }^{62)}$ Therefore, the monoclonal antibody against IL-6 is hypothesized to reduce this process and improve clinical outcomes; tocilizumab is one such IL-6 antagonist agent. ${ }^{41)}$ It is usually administered to patients with rheumatoid arthritis or cytokine release syndrome and has been proven safe and effective. ${ }^{63)}$

A case report of a child with COVID-19 who had overlapping features of toxic shock syndrome and Kawasaki disease was given tocilizumab $8 \mathrm{mg} / \mathrm{kg}$ IV at 72 hours after IVIG infusion. Clinical resolution was seen at 12 hours after administration, and the previously elevated inflammatory marker levels were reduced to baseline. ${ }^{64)}$ The study is supported by a report of a 16 -yearold girl with severe sickle cell disease who developed acute coronary syndrome and ARDS in conjunction with a positive SARS-CoV-2 result that was known to have been acquired from her parents. The plasma IL-6 level was extremely elevated, and tocilizumab $8 \mathrm{mg} / \mathrm{kg}$ was administered. Interestingly, respiratory improvement was seen after therapy, such as NIV removal, no oxygen requirement, and ICU discharge. ${ }^{65)}$ The national guideline recommends that tocilizumab be administered in cases of extensive bilateral lung lesion opacity, or in several/critical ill patients with increased IL-6 level. The initial dose is $4-8 \mathrm{mg} / \mathrm{kg}$, with the recommended dose of $400 \mathrm{mg}$ diluted in $0.9 \%$ normal saline to a final volume of $100 \mathrm{~mL}$ that is infused over more than 1 hour. If the initial dose does not result in improvement, one additional dose can be administered after 12 hours. The maximum limit is 2 doses. $^{66)}$

\section{4) Plasmapheresis}

Sun et al. ${ }^{17)}$ reported a 1-year-old patient treated with plasmapheresis. He was critically ill with complications of septic shock, multiorgan dysfunction, kidney stones, hydronephrosis, heart failure, and coagulopathy. The duration of therapy and underlying disease were unknown, but he was discharged afterward. To our knowledge, there is no specific guideline for treating COVID-19 in children using plasmapheresis. However, the potential use of this modality was developed in some studies and hypotheses in adults, such as using therapeutic plasma exchange, which might be beneficial for patients with fulminant COVID-19 since could have sepsis, ARDS, or multiorgan failure, which are uncommon COVID-19 symptoms. It likely has significant ability to improve disease severity by reducing inflammatory cytokines, strengthening the endothelial membrane, and decreasing the state of hypercoagulopathy, as cytokine storm may have occurred. ${ }^{67}$ In another case report, 10 adult patients with severe COVID-19 administered convalescence plasma showed rapid eradication of the viremia within 7 days, a negative SARS-CoV-2 RNA result, and resolution of the clinical symptoms within 3 days. Although it is a promising treatment for COVID-19, a randomized trial is needed. ${ }^{68)}$

\section{Other treatments}

\section{1) Vaccines}

Identifying and widely distributing a vaccine against SARS$\mathrm{CoV}-2$ is urgently required to end this pandemic. ${ }^{69)}$ Previous studies of vaccines of other coronaviruses aimed to prevent the infection and decrease the disease severity and viral shedding. The core antigens in vaccine development are based on the structural spike (S) glycoprotein or the receptor-binding domains, including live-attenuated, inactivated, subunit and recombinant, viral vector, and DNA vaccines. ${ }^{43}$

To our knowledge, the latest progressive clinical trial of candidate vaccines to prevent COVID-19 was conducted by Moderna working with the National Institute of Allergy and Infectious Disease (ClinicalTrials.gov: NCT04283461). ${ }^{70)}$ The trial started on March 16, 2020 enrolled 155 healthy subjects aged 18-99 years who were classified into $18-55$ years and older than 55 years. This phase I trial is estimated to finish in November 22, 2021 and aims to evaluate the vaccine's safety and immunogenicity. ${ }^{70)}$ The Moderna vaccine uses mRNA- 
1273, a messenger RNA that utilizes a novel approach that does not require viral insertion into the vaccine and encodes a full length of $S$ structural protein of SARS-CoV-2, known as the surface structure of the virus that allows entrance to the host. It is hypothesized that the copied S protein could produce the immunity after being injected into humans. ${ }^{70,71)}$ The early phase II trial is planned to involve 600 subjects, followed by the phase III trial in July. The phase III trial will mainly aim to investigate whether the vaccine can prevent the COVID-19 among highrisk groups. ${ }^{72,73)}$

\section{2) Other anti-inflammatory drugs}

Nonsteroidal anti-inflammatory drugs (NSAIDs) are now widely used in the clinical setting with diverse indications. NSAIDs inhibit 1 of the 2 cyclooxygenases that are involved in the arachidonic acid cascade that leads to the deactivation of prostaglandin synthesis. ${ }^{74}$

In a case-control study, NSAIDs were linked to higher complication rates in the management of lower respiratory tract infections in adults and children, such as worsening pneumonia, pleural effusion, emphysema, and widening of the infection site. ${ }^{75)}$ Given the lack of evidence of its efficacy, regular NSAID use should probably not be recommended as the first-line option for treating the symptoms of COVID-19, ${ }^{76)}$ although the WHO recommendation stated that there are no data regarding severe adverse effects of NSAID administration in patients with COVID-19. ${ }^{34}$

\section{Conclusion}

The quickly progressing COVID-19 pandemic is becoming a global health problem, particularly in the pediatric population. Its specific treatments remain inconclusive and debatable, although they effectively decrease the signs and symptoms. It is suggested that antivirals, immunomodulating agents, or other therapies be used only when the benefits outweigh the risks or in cases of a severe clinical course since we know that children with COVID-19 have relatively milder symptoms and a lower mortality rate. When there is no efficacy proven antiviral agents to date, clinical trials and reports should investigate the mortality and morbidity of this pandemic.

\section{Conflicts of interest}

No potential conflict of interest relevant to this article was reported.

\section{References}

1. Wu YC, Chen CS, Chan YJ. The outbreak of COVID-19: an overview. J Chin Med Assoc 2020;83:217-20.

2. World Health Organization. Novel coronavirus (2019-nCoV) situation report - 1 [Internet]. Geneva (Switzerland): World Health Organization; 2020 [cited 2020 May 24]. Available from: https://www.who.int/ emergencies/diseases/novel-coronavirus-2019.

3. World Health Organization. IHR Emergency Committee on Novel Coronavirus (2019-nCoV) [Internet]. Geneva (Switzerland): World Health Organization; 2020 [cited 2020 May 10]. Available from: https:// www.who.int/dg/speeches/detail/who-director-general-s-statement-onihr-emergency-committee-on-novel-coronavirus-(2019-ncov).

4. World Health Organization. Coronavirus disease COVID-2019: situation report - 162 [Internet]. Geneva (Switzerland): World Health Organization; 2020 [cited 2020 May 10]. Available from: https://www.who. int/docs/default-source/coronaviruse/20200630-covid-19-sitrep-162. pdf?sfvrsn=e00a5466_2.

5. Park SE. Epidemiology, virology, and clinical features of severe acute respiratory syndrome -coronavirus-2 (SARS-CoV-2; coronavirus disease19). Clin Exp Pediatr 2020;63:119-24.

6. Zhu N, Zhang D, Wang W, Li X, Yang B, Song J, et al. A novel coronavirus from patients with pneumonia in China, 2019. N Engl J Med 2020; 382:727-33.

7. The Novel Coronavirus Pneumonia Emergency Response Epidemiology Team. The epidemiological characteristics of 2019 novel coronavirus diseases (COVID-19) in Jingmen, China. China CDC Wkly 2020;2:11322.

8. World Health Organization. Novel coronavirus [Internet]. Geneva (Switzerland): World Health Organization; 2020 [cited 2020 May 10]. Available from: https://www.who.int/csr/don/12-january-2020-novelcoronavirus-china/en/.

9. Wang C, Horby PW, Hayden FG, Gao GF. A novel coronavirus outbreak of global health concern. Lancet 2020;395:470-3.

10. Ludvigsson JF. Systematic review of COVID-19 in children shows milder cases and a better prognosis than adults. Acta Paediatr 2020;109:108895.

11. Xu Y, Li X, Zhu B, Liang H, Fang C, Gong Y, et al. Characteristics of pediatric SARS-CoV-2 infection and potential evidence for persistent fecal viral shedding. Nat Med 2020;26:502-5.

12. Shekerdemian LS, Mahmood NR, Wolfe KK, Riggs BJ, Ross CE, McKiernan CA, et al. Characteristics and outcomes of children with coronavirus disease 2019 (COVID-19) infection admitted to US and Canadian pediatric intensive care units. JAMA Pediatr 2020 May 11 [Epub]. https://doi.org/10.1001/jamapediatrics.2020.1948.

13. Choi SH, Kim HW, Kang JM, Kim DH, Cho EY. Epidemiology and clinical features of coronavirus disease 2019 in children. Clin Exp Pediatr 2020;63:125-32.

14. Qiu H, Wu J, Hong L, Luo Y, Song Q, Chen D. Clinical and epidemiological features of 36 children with coronavirus disease 2019 (COVID-19) in Zhejiang, China: an observational cohort study. Lancet Infect Dis 2020;20:689-96.

15. Dhochak N, Singhal T, Kabra SK, Lodha R. Pathophysiology of COVID-19: why children fare better than adults? Indian J Pediatr 2020;87:537-46.

16. Cristiani L, Mancino E, Matera L, Nenna R, Pierangeli A, Scagnolari C, et al. Will children reveal their secret? The coronavirus dilemma. Eur Respir J 2020;55:2000749.

17. Sun D, Li H, Lu XX, Xiao H, Ren J, Zhang FR, et al. Clinical features of severe pediatric patients with coronavirus disease 2019 in Wuhan: a single center's observational study. World J Pediatr 2020;16:251-9.

18. Saheb Sharif-Askari N, Saheb Sharif-Askari F, Alabed M, Temsah MH, Al Heialy S, Hamid Q, et al. Airways expression of SARS-CoV-2 receptor, ACE2, and TMPRSS2 is lower in children than adults and increases with smoking and COPD. Mol Ther Methods Clin Dev 2020;18:1-6.

19. Cao Q, Chen YC, Chen CL, Chiu CH. SARS-CoV-2 infection in children: transmission dynamics and clinical characteristics. J Formos Med Assoc 2020;119:670-3.

20. Lyu J, Miao T, Dong J, Cao R, Li Y, Chen Q. Reflection on lower rates of COVID-19 in children: does childhood immunizations offer unexpected protection? Med Hypotheses 2020;143:109842.

21. Carsetti R, Quintarelli C, Quinti I, Piano Mortari E, Zumla A, Ippolito 
$\mathrm{G}$, et al. The immune system of children: the key to understanding SARSCoV-2 susceptibility? Lancet Child Adolesc Health 2020;4:414-6.

22. Niewiesk S. Maternal antibodies: clinical significance, mechanism of interference with immune responses, and possible vaccination strategies. Front Immunol 2014;5:446.

23. Chiotos K, Hayes M, Kimberlin DW, Jones SB, James SH, Pinninti SG, et al. Multicenter initial guidance on use of antivirals for children with COVID-19/SARS-CoV-2. J Pediatric Infect Dis Soc 2020 Apr 22:piaa045. https://doi.org/10.1093/jpids/piaa045. [Epub].

24. Chan JF, Yuan S, Kok KH, To KK, Chu H, Yang J, et al. A familial cluster of pneumonia associated with the 2019 novel coronavirus indicating personto-person transmission: a study of a family cluster. Lancet 2020;395:51423.

25. Liu W, Zhang Q, Chen J, Xiang R, Song H, Shu S, et al. Detection of COVID-19 in Children in Early January 2020 in Wuhan, China. N Engl J Med 2020;382:1370-1.

26. Lu X, Zhang L, Du H, Zhang J, Li YY, Qu J, et al. SARS-CoV-2 infection in children. NEngl J Med 2020;382:1663-5.

27. Dong Y, Mo X, Hu Y, Qi X, Jiang F, Jiang Z, et al. Epidemiological characteristics of 2143 pediatric patients with 2019 coronavirus disease in China. Pediatrics 2020. https://doi.org/10.1542/peds.2020-0702.

28. CDC COVID-19 Response Team. Coronavirus disease 2019 in children - United States, February 12-April 2, 2020. MMWR Morb Mortal Wkly Rep. 2020;69:422-6.

29. Parri N, Lenge M, Buonsenso D; Coronavirus Infection in Pediatric Emergency Departments (CONFIDENCE) Research Group. Children with COVID-19 in Pediatric Emergency Departments in Italy. N Engl J Med 2020;383:187-90.

30. Gugus Tugas Percepatan Penanganan COVID-19. Data sebaran kasus COVID-19 [Internet]. Jakarta (Indonesia): Gugus Tugas Percepatan Penanganan COVID-19; 2020 [cited 2020 Jul 1]. Available from: https:// www. covid19.go.id/.

31. Shen K, Yang Y, Wang T, Zhao D, Jiang Y, Jin R, et al. Diagnosis, treatment, and prevention of 2019 novel coronavirus infection in children: experts' consensus statement. World J Pediatr 2020;16:223-31.

32. Rahimzadeh G, Noghabi ME, Elyaderani FK, Navaeifar MR, Enayati AA, Anari AM, et al. COVID-19 infection in iranian children: a case series of 9 patients. J Pediatr Rev 2020;139-44.

33. Cai J, Xu J, Lin D, Yang Z, Xu L, Qu Z, et al. A case series of children with 2019 novel coronavirus infection: clinical and epidemiological features. Clin Infect Dis 2020 Feb 28:ciaa198. https://doi.org/10.1093/ $\mathrm{cid} / \mathrm{ciaa} 198$

34. World Health Organization. Clinical management of COVID-19: interim guidance, 27 May 2020. Geneva (Switzerland): World Health Organization; 2020.

35. García-Salido A, Leoz-Gordillo I, Martínez de Azagra-Garde A, NietoMoro M, Iglesias-Bouzas MI, García-Teresa MÁ, et al. Children in critical care due to severe acute respiratory syndrome coronavirus 2 infection: experience in a Spanish Hospital. Pediatr Crit Care Med 2020 May 27:10.1097/PCC.0000000000002475. https://doi.org/10.1097/ PCC. 0000000000002475 .

36. Carlotti APCP, Carvalho WB, Johnston C, Rodriguez IS, Delgado AF. COVID-19 Diagnostic and Management Protocol for Pediatric Patients. Clinics (Sao Paulo) 2020;75:e1894.

37. Chen ZM, Fu JF, Shu Q, Chen YH, Hua CZ, Li FB, et al. Diagnosis and treatment recommendations for pediatric respiratory infection caused by the 2019 novel coronavirus. World J Pediatr 2020;16:240-6.

38. Wang Y, Zhu LQ. Pharmaceutical care recommendations for antiviral treatments in children with coronavirus disease 2019. World J Pediatr 2020;16:271-4.

39. Falzarano D, de Wit E, Rasmussen AL, Feldmann F, Okumura A, Scott DP, et al. Treatment with interferon- $\alpha 2 b$ and ribavirin improves outcome in MERS-CoV-infected rhesus macaques. Nat Med 2013;19:1313-7.

40. Lou XX, Shi CX, Zhou CC, Tian YS. Three children who recovered from novel coronavirus 2019 pneumonia. J Paediatr Child Health 2020; 56:650-1.

41. Sanders JM, Monogue ML, Jodlowski TZ, Cutrell JB. Pharmacologic treatments for coronavirus disease 2019 (COVID-19): a review. JAMA 2020 Apr 13 [Epub]. https://doi.org/10.1001/jama.2020.6019.

42. Kang CK, Seong MW, Choi SJ, Kim TS, Choe PG, Song SH, et al. In vitro activity of lopinavir/ritonavir and hydroxychloroquine against severe acute respiratory syndrome coronavirus 2 at concentrations achievable by usual doses. Korean J Intern Med 2020;35:782-7.

43. Zimmermann P, Curtis N. Coronavirus infections in children including COVID-19: an overview of the epidemiology, clinical features, diagnosis, treatment and prevention options in children. Pediatr Infect Dis J 2020;39:355-68.

44. Wang M, Cao R, Zhang L, Yang X, Liu J, Xu M, et al. Remdesivir and chloroquine effectively inhibit the recently emerged novel coronavirus (2019-nCoV) in vitro. Cell Res 2020;30:269-71.

45. US Food and Drug Administration. FDA issues emergency use authorization for potential COVID-19 treatment [Internet]. Silver Spring (MD): US Food and Drug Administration; 2020 [cited 2020 Jun 10]. Available from: https://www.fda.gov/media/137566/download.

46. Grein J, Ohmagari N, Shin D, Diaz G, Asperges E, Castagna A, et al. Compassionate use of remdesivir for patients with severe Covid-19. N Engl J Med 2020;382:2327-36.

47. Kadam RU, Wilson IA. Structural basis of influenza virus fusion inhibition by the antiviral drug Arbidol. Proc Natl Acad Sci US A 2017;114:206-14.

48. Indonesian Pediatric Society. Panduan Klinis Tata Laksana COVID-19 pada Anak. Jakarta (Indonesia): Indonesian Pediatric Society, 2020.

49. Burhan E, Susanto AD, Nasution SA, Ginanjar E, Pitoyo CW, Susilo A, et al. Jakarta (Indonesia): Perhimpunan Dokter Paru Indonesia (PDPI) Perhimpunan Dokter Spesialis Kardiovaskular Indonesia (PERKI) Perhim. punan Dokter Spesialis Penyakit Dalam Indonesia (PAPDI) Perhimpunan Dokter Anestesiologi dan Terapi Intensif Indonesia (PERDATIN) Ikatan Dokter Anak Indonesia (IDAI), 2020.

50. Hedrich CM. COVID-19 - considerations for the paediatric rheumatologist. Clin Immunol 2020;214:108420.

51. Henderson LA, Canna SW, Schulert GS, Volpi S, Lee PY, Kernan KF, et al. On the alert for cytokine storm: immunopathology in COVID-19. Arthritis Rheumatol 2020;72:1059-63.

52. Coperchini F, Chiovato L, Croce L, Magri F, Rotondi M. The cytokine storm in COVID-19: an overview of the involvement of the chemokine/ chemokine-receptor system. Cytokine Growth Factor Rev 2020;53:2532.

53. Shi Y, Tan M, Chen X, Liu Y, Huang J, Ou J, et al. Immunopathological characteristics of coronavirus disease 2019 cases in Guangzhou, China. medRxiv 2020.03.12.20034736. https://doi.org/10.1101/2020.03.12.2 0034736.

54. Ye Q, Wang B, Mao J. The pathogenesis and treatment of the Cytokine Storm' in COVID-19. J Infect 2020;80:607-13.

55. Lee KY, Rhim JW, Kang JH. Early preemptive immunomodulators (Corticosteroids) for severe pneumonia patients infected with SARSCOV-2. Clin Exp Pediatr 2020;63:117-8.

56. Li H, Chen C, Hu F, Wang J, Zhao Q, Gale RP, et al. Impact of corticosteroid therapy on outcomes of persons with SARS-CoV-2, SARSCoV, or MERS-CoV infection: a systematic review and meta-analysis. Leukemia 2020;34:1503-11.

57. Ahn JY, Sohn Y, Lee SH, Cho Y, Hyun JH, Baek YJ, et al. Use of convalescent plasma therapy in two COVID-19 patients with acute respiratory distress syndrome in Korea. J Korean Med Sci 2020;35:e149.

58. Gasparyan AY, Misra DP, Yessirkepov M, Zimba O. Perspectives of immune therapy in coronavirus disease 2019. J Korean Med Sci 2020;35: e176.

59. World Health Organization. Multisystem inflammatory syndrome in children and adolescents temporally related to COVID-19 [Internet]. Geneva (Switzerland): World Health Organization; 2020 [cited 2020 Jun 10]. Available from: https://www.who.int/news-room/commentaries/ detail/multisystem-inflammatory-syndrome-in-children-and-adolescentswith-covid-19.

60. Riphagen S, Gomez X, Gonzalez-Martinez C, Wilkinson N, Theocharis P. Hyperinflammatory shock in children during COVID-19 pandemic. Lancet 2020;395:1607-8. 
61. Jones VG, Mills M, Suarez D, Hogan CA, Yeh D, Segal JB, et al. COVID-19 and Kawasaki disease: novel virus and novel case. Hosp Pediatr 2020;10:537-40.

62. Ulhaq ZS, Soraya GV. Interleukin-6 as a potential biomarker of COVID-19 progression. Med Mal Infect 2020;50:382-3.

63. Fu B, Xu X, Wei H. Why tocilizumab could be an effective treatment for severe COVID-19? J Transl Med 2020;18:164.

64. Balasubramanian S, Nagendran TM, Ramachandran B, Ramanan AV. Hyper-inflammatory syndrome in a child with COVID-19 treated successfully with intravenous immunoglobulin and tocilizumab. Indian Pediatr 2020;57:681-3.

65. Odièvre MH, de Marcellus C, Ducou Le Pointe H, Allali S, Romain AS, Youn J, et al. Dramatic improvement after tocilizumab of severe COVID-19 in a child with sickle cell disease and acute chest syndrome. Am J Hematol 2020;95:E192-4.

66. National Health Commission \& National Administration of Traditional Chinese Medicine. Diagnosis and treatment protocol for novel coronavirus pneumonia (trial version 7). Chin Med J (Engl) 2020;133:108795.

67. Keith P, Day M, Perkins L, Moyer L, Hewitt K, Wells A. A novel treatment approach to the novel coronavirus: an argument for the use of therapeutic plasma exchange for fulminant COVID-19. Crit Care 2020;24:128.

68. Duan K, Liu B, Li C, Zhang H, Yu T, Qu J, et al. Effectiveness of convalescent plasma therapy in severe COVID-19 patients. Proc Natl Acad
SciUS A 2020;117:9490-6.

69. Balkhair AA. COVID-19 pandemic: a new chapter in the history of infectious diseases. Oman Med J 2020;35:e123.

70. ClinicalTrials.gov. Safety, reactogenicity, and immunogenicity of mRNA1273 COVID-19 vaccine in adults aged 18 years and older [Internet]. Bethesda (MD): ClinicalTrials.gov; 2020 [cited 2020 Jun 10]. Available from: https://clinicaltrials.gov/.

71. Wang F, Kream RM, Stefano GB. An evidence based perspective on mRNA-SARS-CoV-2 vaccine development. Med Sci Monit 2020;26: e924700.

72. Mullard A. COVID-19 vaccine development pipeline gears up. Lancet 2020;395:1751-2

73. Callaway E. Coronavirus vaccine trials have delivered their first results but their promise is still unclear. Nature 2020;581:363-4.

74. Micallef J, Soeiro T, Jonville-Béra AP. Non-steroidal anti-inflammatory drugs, pharmacology, and COVID-19 infection. Therapie 2020 May 7 [Epub]. https://doi.org/10.1016/j.therap.2020.05.003.

75. Voiriot G, Philippot Q, Elabbadi A, Elbim C, Chalumeau M, Fartoukh $\mathrm{M}$. Risks related to the use of non-steroidal anti-inflammatory drugs in community-acquired pneumonia in adult and pediatric patients. J Clin Med 2019;8:786.

76. Little P. Non-steroidal anti-inflammatory drugs and covid-19. BMJ 2020; 368:m1185. 